\title{
The Role of International Administration [IA] in the Globally Engaged University
}

\author{
Timothy Todd Diemer \\ Director, International Programs, \\ Assistant Professor, Organizational Leadership \\ Purdue School of Engineering \& Technology \\ Indiana University - Purdue University Indianapolis \\ IUPUI, Indianapolis, IN USA \\ David J. Russomanno \\ Dean, Professor of Electrical and Computer Engineering, \\ Purdue School of Engineering and Technology, IUPUI, \\ M. Razi Nalim \\ Executive Associate Dean, Research \& Graduate Programs, \\ Professor of Mechanical Engineering, \\ Purdue School of Engineering and Technology, IUPUI
}

\author{
Agnieszka Piekarzewska \\ Director of International Relations, Professor of Economics, \\ Wyższa Szkoła Komunikacji i Zarządzania, \\ Poznań, Poland,
}

Dato' Dr Shaari B.Md.Nor

Prof. Madya, Mejar

Aras 1, Bangunan BB, Yayasan Tenaga Nasional

Universiti Tenaga Nasional -UNITEN,

KM7, Jalan Ikram-Uniten, 43009 Kajang, Selangor, Malaysia

Keywords-Globally Engaged University; international administration; RCM; project management approach; internationalization.

\section{ABSTRACT}

This paper describes best practice and effective techniques in international administration (IA) within the Globally Engaged University. The Globally Engaged University is one that continually promotes, communicates, initiates, controls, monitors, and evaluates international activity in at least one of its major academic units [5]. Emphasis is IA within engineering and technology higher education. Nonetheless, the description of best practice in IA is also applicable to various other academic disciplines at the Globally Engaged University.

In describing best practice in IA, the paper adds the perspective of the authors' applied experience. The combined IA experience among the co authors includes successful international programs in South and Southeast Asia, the European Union, and the USA. Three of the co-authors are senior administrators within one and the same university in the USA. Another co-author is a senior administrator at a university in Malaysia. Broadening the perspective yet further, another team member is an IA specialist at a Globally Engaged University in Poland. The authors compare and contrast techniques and organizational structure common to IA at three differing locations: USA, Malaysia, and Poland as a central member state of the European Union.

\section{STRATEGIC PLAN}

Long range planning at many universities today involves the techniques of strategic planning [14]. When the strategic plan includes a vision [3] for global learning and international collaboration, the university is on the path to becoming a Globally Engaged University.

The European context emphasizes the importance of strategic planning. The presence of a well established strategic plan becomes essential for EU members in light of the Erasmus + initiative. Erasmus + puts focus on internationalization of education and training for participants of all age groups. The program operates under the European Union's budget perspective 2014-2020. The initiative was launched under the Erasmus name in 1987. Erasmus + has become the main incentive for encouraging internationalization of higher education institutions (HEI). HEI in this context refers to universities and colleges that offer the diploma or the degree beyond the secondary-school qualification. The designation HEI applies to any higher-education institution that has been recognized as a valid degree or diploma-granting institution by the governing authority.

Erasmus + encourages mobility as part of the HEI internationalization efforts. Mobility in this use refers to student and staff exchange between two or more HEIs along with mutual recognition of learning outcomes. During the 30 years of its existence, the Erasmus program has become the brand name for international academic collaboration across the EU and beyond. The Erasmus ${ }^{+}$program currently operates in 33 countries, including the European Union as well as Iceland, Liechtenstein, Norway, Turkey, and the Former Yugoslav Republic of Macedonia. The vast majority of HEIs in each EU member country participate in the program.

This is the author's manuscript of the article published in final edited form as: 
The Erasmus opportunities underscore why the Globally Engaged University or college does well to include an international emphasis within its strategic plan. To participate in Erasmus+, the member HEI is required to present in a publicly accessible manner, such as the main web pages, the HEI's strategy for internationalization. Furthermore, when an HEI prepares an application for a Key-Action described by Erasmus + documentation, reference to the Erasmus+ Charter for Higher Education (ECHE), and its connection to the strategic plan for internationalization, becomes sine qua non for success of the application [6].

The Erasmus + program offers an Organisational Support grant (OS grant) to all HEIs that conduct Erasmus + activities, such as mobility programs. The level of OS funding is the same for HEIs in all participating countries. As of this writing, the amount is approximately $€ 350$ times the number of mobilities. The funding granted to the HEI through this channel is meant to encourage members to cooperate in promoting international activity by alleviating the administrative cost. The grant may also be used for mobility programs with non members as well as with Erasmus member countries. As a result, there is incentive for Erasmus HEIs to reach out to Globally Engaged Universities in other countries around the globe [7].

The importance of internationalization within the HEI strategic plan is underscored again in the policy set forth by the Ministry of Higher Education, Malaysia. The Blueprint for Education 2015-2025 (Higher Education) puts unambiguous emphasis on mobility programs and other international activities in guidelines for Malaysia's diploma and degree-granting HEIs [12]. This incentive has already resulted in productive new agreements between the Purdue School of Engineering and Technology, Indiana UniversityPurdue University Indianapolis (PSET, IUPUI), and two strategic universities in Malaysia, Universiti Teknologi Malaysia Melaka, and Universiti Tenaga Nasional.

\section{INTRODUCTION TO IA}

When the strategic plan has been published, propagated, and activated, a new university, or a university where the focus is primarily local, will follow a process to build its international portfolio [5]. An essential building block of the international portfolio is effective IA.

Depending on size, academic mission, and administration structure at the Globally Engaged University, IA may be a single centralized unit, or IA may be decentralized at each participating academic unit (whether designated locally as faculty or college or school). Regardless, IA at the Globally Engaged University can play a major role in realizing the vision for international activity as described within the strategic plan.

\section{PROJECT-MANAGEMENT APPROACH}

For purposes of efficient management, it is useful to consider international activities as a collection of smaller projects. For example, for administration purposes, any of the following can be considered projects under the umbrella of an IA office: A government or private sector grant for a specific international activity, such as the OS grants described above, or a new exchange program with a partner university, or an initiative to meet accreditation guidelines by expanding the international components of the curriculum.

When the project-management approach is taken, then essential questions are answered using standard project-management techniques [9]. Essential questions for planners that can be answered via the project-management approach include:

What are project goals and anticipated outcomes? What are project deliverables? Who is able and willing to serve as project manager and who will comprise the project team? What are timelines for each deliverable? Who are project stakeholders? What methods of communication with project stakeholders will the project team employ? What will the project cost and where are funding sources? How will cost effectiveness be measured?

As a means of presenting an approach to effective IA, each of these questions is answered in some detail below.

\section{A. Who is the project manager and who are the project team?}

Selection of the project manager for each project within the portfolio of a Globally Engaged University depends largely on local preferences. In some cases the IA director or coordinator is a current faculty or staff member who has IA added to his or her duties. In other cases, the IA director is an administrative specialist assigned primarily to the task of leading IA. For smaller international projects, a single person may serve both as project manager and as a one-person project team, or leadership may be shared among a 2-3 member team.

Whether the project director is drawn from current faculty and staff members and assigned IA as a portion of his/her time, or whether the role is dedicated to IA alone, the question of compensation is one that must be addressed. The notion that a current full-time faculty or staff member can be assigned to IA on top of normal duties without additional compensation only shows that the university has less than full commitment to global engagement and internationalization. 
Compensation should be commensurate with expected value added. As described below, responsibility-centered budgeting can show clearly whether value added is at least equal to compensation. Instead of monetary compensation, release time may be granted to a full-time faculty or staff member, resulting, for example, in a reduced teaching load, or corresponding reduction in other assigned duties. This is common practice in the USA. In any case, compensation must provide adequate incentive to motivate the project manager to pursue vigorously the international components of the university strategic plan.

\section{B. What are project goals/expected outcomes and what are the project deliverables?}

The overall goal of each project derives from the strategic plan of the university at large. In turn, the IA office does well to establish a subservient vision statement, mission statement, and comprehensive goals that describe its raison d'être and its planned cost effectiveness.

The overall goal and goals for each project help IA to define what activities are in scope and what are out of scope. The project scope and the efforts and activities that achieve the project goals become a perimeter for the project [9] [15]. The defined project scope, along with project goals, determine project deliverables. Deliverable in this case refers to products or activities that demonstrate progress toward the defined project outcomes. For example, if establishing a reciprocal exchange program is the project goal, then arranging for the exchange of 1-3 students in each direction for a coming semester or a coming year is a modest deliverable within a specified time period. Preparing and sending information about the student visa is activity that is clearly within the project scope. Offering academic advising to prospective participants is in scope to the extent that the advising is centered on how an exchange program fits into a student's overall plan of study for the degree program.

\section{Who are stakeholders?}

The project management body of knowledge provided a guiding definition of stakeholders:

Project stakeholders are individuals and organizations that are actively involved in the project, or whose interests may be positively or negatively affected as a result of project execution or project completion; they may also exert influence over the projects and its results [9].

Early identification of stakeholders is an essential step in planning any project. The small to medium-sized projects managed by the university IA office are no exception. Early in the lifecycle of an international project, the project manager and his/her team must seek and document the interests of key stakeholders and manage their expectations [15]. In the case of a mobility program that offers undergraduate students from Universiti Tenaga Nasional (UNITEN) in Malaysia the opportunity to earn the Purdue Bachelor of Science degree at IUPUI, for example, stakeholders are manifold.

The students themselves are primary stakeholders and the parents and families of each participant are often numbered among key stakeholders as well. The sponsoring agency, Yayasan Tenaga Nasional (YTN or the Tenaga Foundation), is also a key stakeholder. The faculty members and administrators at IUPUI are also stakeholders in that they do well to adjust to the learning needs that comprise a diverse learning group. American classmates of the Malaysian students are also stakeholders, primarily because they stand to gain experience working cooperatively in an internationally diverse team on engineering-design tasks.

The accreditation body for the academic unit is also a stakeholder. A core learning outcome specified by ABET, the American accreditation body for most engineering and technology degree programs in the USA, specifies that in addition to, "an ability to function on multidisciplinary teams," a core competency that graduates must demonstrate is,

- "The broad education necessary to understand the impact of engineering solutions in a global, economic, environmental, and societal context" [1]. and

- "An understanding of and a commitment to address professional and ethical responsibilities including a respect for diversity" $[2]$.

Administrators both at UNITEN and IUPUI are stakeholders as well, in that they have a role in making the participant transition to life and study in the USA a smooth one, so that participants can devote their attention to their studies. Finally, the employers who seek and hire engineers with skills needed to succeed in the global workforce are stakeholders. Identification of stakeholders is a core building block for best practice in international project management.

\section{What are timelines for each deliverable?}

If the work of the IA office is viewed as a series of small and large projects under a single administrative unit, then efficient management requires a project timeline for each project. The PMBOK Guide [9] summarized a range of techniques to chart start and end dates for each project activity and each short-term deliverable on the way to project completion. The coordinator's role in 
marshaling personnel in service to the project is greatly aided when each team member has reference to a master timeline for the project.

For larger international projects, it is useful to publish the IA project timeline in a format that is easily accessible to all members of the project team. A time-honored method is to produce a wall chart that everyone passes in the course of their day. Nowadays graphical representations of timelines are easily produced with the aid of common office-management software. In addition to a bulletin board presentation, a computer representation on the shared server space provides an additional reference for team members, one that can be assessed during time traveling or time at home, for the many in the USA and elsewhere who do some of their work before and after normal working hours [10].

The wall chart or computer representation to display the project timeline also provides the team with an opportunity to celebrate small victories, a concept that Kotter promoted in his well-known work on organizational change [11]. Smaller accomplishments in meeting anticipated completion dates become visible to all members and can easily be celebrated with positive feedback, a technique well known as a motivator for continued progress [8]. Viewed in this light, recognition in the newsletter for progress toward a goal may be more effective than the monetary value of a gift certificate for Starbucks.

\section{E. What methods of communication with project stakeholders will the project team employ?}

More than 3/4 of the manager's time is spent in communication, whether formal or informal, whether spoken or written, whether business letters or electronic modes [8]. Project managers most certainly fit this generalization.

An essential technique of project management is communication via status reports, composed by the project team, and distributed to stakeholders who need to know. Rowe [15] favors construction of a communication matrix to show who among stakeholders should be informed of project updates and when they need to know. No one likes unpleasant surprises. A communication matrix helps the project team avoid the spectacle of a delivering a nasty surprise to a key stakeholder at project completion.

F. What will the project cost and where are funding sources?

In the case of a fixed cost contract from a funding source, the lump-sum cost of the project is fixed. However, many funding sources require a detailed budget to show how the funds will be spent. Even when this requirement is absent, a detailed budget is useful to demonstrate to central university administration that the project has been completed within the designated cost perimeter.

A budget shows project planners and university central administration the extent to which IA is cost effective. The budget should include known costs in staff time, required resources, space utilization, and travel. When the project goal is to establish and maintain a new mobility program, questions arise about who pays for what. Are the costs of international travel and local transport paid by participants, by the home university, or by the host university? These questions are answered by an internal budget. Answers to these questions must also be communicated to all stakeholders who need to know, most certainly the travelers themselves.

\section{G. How will cost effectiveness be measured?}

The authors maintain that the IA function of managing international projects is cost effective. Cost effectiveness of the IA unit is more readily measured when the university employs a budgetary model that fits the category of cost-center budgeting, also known as responsibility-centered management $(\mathrm{RCM})$. The approach is an application the cost-center approach commonly found within the commercial market. An explanation of RCM, along with a description of how it is used to measure IA cost effectiveness at one engineering-technology academic unit, follows.

RCM has introduced substantial change to a number of universities in the USA [4]. The RCM model has been particularly effective as an administrative enabler at Indiana University-Purdue University Indianapolis (IUPUI), a public university with current enrolment of 30,000 and a wide array of degree programs, ranging from medical to law to engineering to informatics to business and others.

One result of RCM at IUPUI has been to enable the Purdue School of Engineering and Technology to build effective, reciprocal, and cost effective international programming and globalization efforts. Furthermore, RCM has been a fundamental enabler for the School to pursue its vision statement:

To be regarded as one of America's premier urban schools of engineering and technology, recognized regionally, nationally, and internationally, for its excellence in teaching and learning, research/creative activities, and civic engagement.

The RCM budget model - in contrast with the more typical centralized approach to budgeting is meant to empower degree-granting academic units (Schools, Colleges, Faculties) by permitting the carryforward of financial reserves from one fiscal year to the next. 
The carry-forward capability allows for accumulation of the requisite resources to fund strategic -and at times unique- priorities specific to the academic unit.

The carry forward capability of RCM is in direct contrast to the more traditional spend-it or-lose-it rules that are prevalent within more traditional budgetary environments. Under RCM, each academic unit (responsibility center or cost center), is required to build the annual base budget based on projected revenue streams generated from areas such as student fees, research, indirect-cost recovery (overhead), government appropriation, and/or philanthropic support, along with any other revenue source, such as proceeds from technology transfer. Whenever the documented origin of the funds is the academic unit itself, the income returns to the specific academic unit, minus a percentage fee levied by central administration of the university at large.

The academic unit's expenditures must not exceed revenue from one or more of its funding sources. When expenditures do exceed the planned allocation, central administration will compel the academic unit to reduce costs and reallocate funds. The directive is likely to require immediate response by the academic unit and must be reflected in construction of the budget for the following year. Obviously, this scenario is one that the academic unit seeks to avoid in all cases, as it can result in financial disaster, such as insufficient funds for staffing key positions in the following year.

The strong incentive to stay within budget year by year in turn compels the academic unit to gather data in real time to monitor enrollment and cost effectiveness of various initiatives. Cost effectiveness directly affects the desired ratio of staffing as a percentage of enrollment. As a result the workload assigned to personnel, whether they be faculty members, staff members, or administrators, must be monitored year-by-year, and semester-by-semester. An increase in part-time and adjunct faculty members is one solution to the problems of fluctuation in enrollment.

The academic unit must also monitor its outreach to the community it serves. Market forces and trends affecting stakeholders can directly impact the cost effectiveness of the academic unit in its mission to serve its community.

In the US system, the academic deans are primarily responsible for leading the strategic planning and implementation of initiatives to advance an academic unit. As summarized by [13], the RCM model shifts the dean's role from a supplicant pleading with central administration for financial resources, to assuming full responsibility for accruing and managing the resources required to advance the strategic priorities of the academic unit. The ability to pursue strategic goals is directly correlated to the unit's revenue generating capacity.

Given the resulting RCM decentralized environment, academic units are often involved in a variety of atypical initiatives. Examples include strategic and customized development of resources devoted to international activities, various services units such as student services specific to the academic unit, and co-curricular activities to enhance the learning environment.

Indiana University, which is the managing partner of IUPUI, became one of the first public universities to implement the RCM budget model in the late 1980s [4]. There is a longer history of RCM implementation among private universities within the USA, including Harvard and the University of Southern California. Based on a recent review of RCM at IUPUI, academic deans reaffirmed that RCM encourages entrepreneurship. It enables academic units to maintain primary control over their budgets and retain their reserve funds for strategic priorities. The deans who gathered for the review further agreed that RCM fosters cooperation among deans and their academic units whenever they see advantage in pooling resources to pursue shared strategic priorities.

In light of RCM requirements, can an academic unit justify the cost of staff assigned specifically to plan, activate, and monitor international-programs administrators? In the case of the Purdue School of Engineering and Technology, IUPUI, the answer is clearly yes. The RCM model has enabled outcomes from strategic actions, including transformation of the School from a regionally focused academic unit to developing a considerable portfolio of international programming in a variety of formats. As of fall semester 2016, approximately $17 \%$ of the School enrolment of over 3,300 showed an international location as home of record. This compares to fewer than $3 \%$ in the early 1990s. Indeed the PSET, IUPUI, is the most internationally diverse academic unit on the IUPUI campus.

\section{USING RCM}

Although the RCM model has been the subject of extensive trade-off analysis with respect to balancing academic entrepreneurship with fiscal responsibility and making sure that a body of knowledge in the humanities is preserved [4], the RCM model should be investigated further with respect to its efficacy in the specific context of advancing international administrative strategies within a Globally Engaged University. The benefits to the university of RCM, as measured by cost effectiveness of its organizational flow chart and support of an international vision, cannot easily be dismissed. 


\section{REFERENCES}

[1] “ABET. Criteria for Accrediting Engineering Programs", Baltimore, MD, 2015, retrieved: http://www.abet.org/wp-content/uploads/2015/10/E001-16-17EAC-Criteria-10-20-15.pdf

[2] “ABET. Criteria for Accrediting Engineering Technology Programs”, Baltimore, MD, 2015, retrieved: http://www.abet.org/wpcontent/uploads/2015/10/T001-16-17-ETAC-Criteria-10-16-15.pdf

[3] M. Allison and J. Kaye, "Strategic planning for nonprofit organizations: A Practical guide for dynamic times" (3rd ed.), Hoboken, NJ: Wiley, 2015, pp.27-75

[4] J. R. Curry, A. L. Laws and J. C. Strauss, "Responsibility center management: A guide to balancing academic entrepreneurship with fiscal responsibility", Washington, DC: National Association of College \& University Business Officers, 2013

[5] T. T. Diemer, M. R. Nalim, A. K. Piekarzewska, and D. J. Russomanno, „From domestic to international: Pathway to the Globally Engaged University”, paper presented at the SIU-AIU Conference on Internationalisation of Higher Education 2017, Pune, India, April 2017, in press

[6] "ECHE Monitoring Guide for Erasmus+ National Agencies, 2016", retrieved: https://ec.europa.eu/programmes/erasmusplus/sites/erasmusplus/files/library/eche-monitoring-guide_en.pdf

[7] "Erasmus+ 2017 Programme Guide", retrieved: http://ec.europa.eu/programmes/erasmus-plus/sites/erasmusplus/files/files/resources/erasmus-plusprogramme-guide_en.pdf

[8] J. Greenberg, "Behavior in organizations", Upper Saddle River, NJ: Prentice Hall, 2011. pp.223-224.

[9] "A Guide to the project management body of knowledge PMBOK guide", Newtown Square, PA: Project Management Institute, ed. 2000. pp.16-18, 42-49, 75-77.

[10] K. Holland, "When is a vacation not vacation? 61\% of the time", USA Today, 23 July 2013, retrieved: http://www.today.com/money/when-vacation-notvacation-61-time-6C10719810

[11] J. P. Kotter, H. Rathgeber and P. Mueller, “Our iceberg is melting: Changing and succeeding under any conditions” (1st ed.)., New York: St. Martin's Press, 2005. p.131

[12] “Malaysia Education Blueprint 2015-2025 (Higher Education)”, Ministry of Higher Education, Malaysia, 2015, retrieved: https://www.mohe.gov.my/en/component/docman/?Itemid=254

[13] A. B. McBride, S. Neiman and J. Johnson, "Responsibility-centered management: A 10-year nursing assessment”, Journal of Professional Nursing, 16(4), 2000, pp. 201-209

[14] T. V. Rao, "Performance Management: Toward Organizational Excellence", India: Sage Publications, 2016, p. xii

[15] S. F. Rowe, "Project management for small projects" (2nd Ed.), Vienna, VA: Management Concepts, 2015, Chapter 5 